\section{Survival of AIDS patients in the Southeast and South of Brazil: analysis of the 1998-1999 cohort}

\author{
Sobrevida de pacientes com AIDS das regiões \\ Sudeste e Sul do Brasil: análise da \\ coorte de 1998 a 1999
}

Ione Aquemi Guibu 1,2

Marilisa Berti de Azevedo Barros 3

Maria Rita Donalísio 3

Ângela Tayra 2

Maria Cecília Goi Porto Alves 4
${ }^{1}$ Faculdade de Ciências Médicas da Santa Casa de São Paulo, São Paulo, Brasil. 2 Centro de Referência e Treinamento em DST/AIDS, Secretaria de Estado da Saúde de São Paulo, São Paulo, Brasil.

${ }^{3}$ Faculdade de Ciências Médicas, Universidade Estadual de Campinas Campinas, Brasil.

4 Instituto de Saúde, Secretaria de Saúde do Estado de São Paulo, São Paulo, Brasil.

Correspondence I. A. Guibu Faculdade de Ciências Médicas da Santa Casa de São Paulo.

Rua Joaquim Antunes 852, apto. 83-A, São Paulo, SP

05415-001, Brasil.

ione@cealag.com.br

\section{Abstract}

The aim of this study was to evaluate survival time for AIDS patients 13 years and older in the South and Southeast regions of Brazil, according to socio-demographic, clinical, and epidemiological characteristics. The sample was selected from all cases diagnosed in 1998 and 1999 and notified to the Epidemiological Surveillance System of the National STD/AIDS Program. Use of a questionnaire allowed analyzing 2,091 patient charts. Based on the Kaplan-Meier method, estimated survival was at least 108 months after diagnosis in $59.5 \%$ of patients in the Southeast and 59.3\% in the South. Cox regression models showed, in both regions, an increase in survival in patients on antiretroviral therapy, those classified as AIDS cases according to the CD4 T-cell criterion, females, and those with more schooling. Other factors associated with longer survival in the Southeast were: white skin color, no history of tuberculosis since the AIDS diagnosis, negative hepatitis B serology, and access to a multidisciplinary health team. In the South, age below 40 years was associated with longer survival.

Acquired Immunodeficiency Syndrome; Survivorship (Public Health); Anti-Retroviral Agents; Mortality

\section{Introduction}

Since identification of the first AIDS cases in Brazil in the early 1980s, the disease has spread slowly and steadily throughout the country, becoming a veritable mosaic of epidemics. In the last two decades, HIV transmission has reached marginalized and vulnerable populations, with an increase in the occurrence of AIDS cases in municipalities (counties) outside the large metropolitan areas, among heterosexuals, especially women, a reduction in injecting drug users (IDU), and stabilization among young people 1 .

There has been a trend towards stabilization of AIDS incidence in Brazil, especially since 1997, but with significant regional differences. The last decade has witnessed a decrease in incidence rates in the South and Southeast regions of the country and an increase in the North, Northeast, and Central. In the Southeast, the incidence rate of 24.4 per 100 thousand in 1999 decreased to 16.8 per 100 thousand in 2005. There was also a reduction in the South, although not as sharp, from 22.2 per 100 thousand inhabitants in 1999 to 20.0 per 100 thousand in 20052 .

From 1980 to 2008, a total of 432,890 AIDS cases were reported in the entire country, of which 80,929 resided in the South and 268,398 in the Southeast. These two geographic regions accounted for $80.7 \%$ of all AIDS cases in Brazil 2 . Of all the cases, $96.8 \%$ were 13 years or older at 
time of AIDS diagnosis, thus defined as adult cases under the Brazilian classification ${ }^{3}$.

Substantial changes in the morbidity and mortality caused by HIV infection were widely documented after introduction of highly active antiretroviral therapy (HAART) 4,5,6,7.

The AIDS mortality rate in Brazil dropped from 9.6 deaths per 100 thousand inhabitants in 1996 to 6 per 100 thousand in 2006. However, during this same period the rates in the North and Northeast showed an important increase, along with a slight rise in the South. The decline in Brazilian mortality rates resulted from a sharp drop in the rate in the Southeast (from 16.3 in 1996 to 7.4 per 100 thousand in 2006) and in part to a reduction in the Central 2 .

With the use of the new therapy, the clinical spectrum of patients with HIV infection was expanded to include not only opportunistic diseases, but also clinical conditions associated with adverse effects of therapy, as well as chronic diseases with progressively increasing incidence during aging 8,9. The longer survival of individuals with HIV infection/AIDS has been observed not only in developed countries, but also in poor regions of the world where access to HAART has been expanded, as in some countries of SubSaharan Africa 10. A 50\% reduction in mortality was observed in a cohort study in New York, in patients undergoing HAART from 1995 to $2000{ }^{8}$.

Brazil experienced a reduction of approximately $50 \%$ in deaths and $80 \%$ in hospitalizations due to AIDS, from 1995 to 2001 1,4,11. Median survival of AIDS patients over 12 years of age was 5.1 months from 1982 to 1989 12. According to Marins et al. 13, individuals diagnosed in 1995 has a median survival of 16 months, and those diagnosed in 1996 had a median survival of 58 months. This noteworthy increase in survival has been attributed to the Ministry of Health's policy for care and prevention since the 1990s, investing in universal, free access to antiretroviral drugs, widespread availability of diagnostic tests and case follow-up, training of health professionals, and the creation of a laboratory network for monitoring drug resistance 1,13 .

Investments in prevention and care for AIDS patients in Brazil require evaluations of their real impact. Updating the patient survival analyses can contribute to monitoring the epidemic's dynamics and measuring the needs for care, as well as assessing strategies for control of the disease in the country.

The aim of this study was to evaluate survival time according to socio-demographic, clinical, and epidemiological characteristics of AIDS patients diagnosed in 1998 and 1999 in the South and Southeast regions of Brazil.

\section{Method}

A non-concurrent cohort study was performed in a sample of AIDS patients 13 years and older, residing in the South and Southeast regions of Brazil, diagnosed in 1998 and 1999 and recorded in the Information System on Diseases of Notification (SINAN). The database was provided by the Brazilian National STD/AIDS Program.

Starting with all cases reported in the two regions in 1998 and 1999, the sample selection initially excluded cases: from municipalities (counties) with fewer than 40 notifications during the period, representing $18 \%$ of the total; with AIDS first diagnosed at death; from an unknown notification unit; or with date of diagnosis later than death or notification. After these exclusions, the remaining cases totaled 29,600 and 8,797 , distributed across 90 and 33 municipalities, respectively, in the Southeast and South.

Sample sizes were determined to allow verification of statistical significance between different median survival times in population subgroups: from 58 to 70 months in the Southeast and 58 to 74 months in the South, whereas 58 months was the estimated median survival time in a previous study 13 .

To test the hypothesis that the risk of dying within a given time span was the same in two population subgroups (I and II), the number de cases to be included in the study was calculated as the ratio between the number of deaths needed to test the hypothesis and the probability of dying during the study period 14 . The number of deaths was expressed as:

$$
d=\frac{\left(z_{\alpha / 2}+z_{\beta}\right)^{2}}{\pi_{I} \pi_{I I} \theta_{R}{ }^{2}},
$$

where $\alpha=0.05 ; \beta=0.20 ; z_{\alpha / 2}$ and $z_{\beta}$ the points on the standardized normal curve and $\pi_{I}=$ $\pi_{I I}=0.5$ the proportions of cases in groups I and II. The probability of dying was expressed as:

$P($ death $)=1-\frac{1}{12}\{\bar{S}(f)+4 \bar{S}(0.5 a+f)+\bar{S}(a+f)\}$,

where $\mathrm{a}=24$ months is the study's case inclusion period; $\mathrm{f}=72$ months is the follow-up period; and the term following a and $\bar{S}$ expresses the estimated mean values for survival functions in groups I and II.

The calculations were performed with the Power and Precision software (Biostat Inc., Englewwod, USA) and indicated the need for a sample of 1,484 patients in the Southeast region and 898 in the South. Since the study predicted losses on the order of $30 \%$, larger numbers of patients were selected: 2,214 and 1,280. 
Composition of the sample for each stratum (region) used two-stage cluster sampling: municipalities and patients. Municipalities were selected with probability proportional to size, defined as the number of notifications to SINAN by health units. Before beginning the selection, the municipalities that lacked the minimum number of notifications to be picked in the second stage were grouped with other, larger municipalities. Thus, the primary sampling units became the municipalities or sets of municipalities. Eighteen were selected in the Southeast and 10 in the South. In the second stage, 123 and 128 patients were selected in each primary unit in the Southeast and South, respectively. The sampling fractions were:

$f=\frac{18 \cdot N_{i}}{29600} \cdot \frac{123}{N_{i}}=\frac{1}{13,369}$ in the Southeast and

$f=\frac{10 \cdot N_{i}}{8797} \cdot \frac{128}{N_{i}}=\frac{1}{6,873}$ in the South, where

$\mathrm{N}_{\mathrm{i}}$ is the number of AIDS cases in the municipality (or set of municipalities) i.

A pre-coded and previously tested questionnaire was prepared to collect data from the clinical charts of selected patients. A manual was prepared for completing the questionnaires, and training was provided for the field researchers and supervisors, who consisted mainly of health professionals working in the STD/AIDS Program. After completion, the questionnaires were submitted to two supervisions, one local and the other central.

Data were collected from November 2006 to December 2007. For purposes of comparison with previous studies 12,13 , the decision was made not to consider the estimated survival for patients that died within 7 days after diagnosis, so no data were collected from these patient charts.

For this study, the independent variables were: gender, age, race/color, marital status, year of diagnosis, schooling, HIV exposure category (all of which reported at the time of AIDS diagnosis), AIDS-defining diagnostic criterion, presence of tuberculosis at diagnosis or during the case evolution, Pneumocystis pneumonia (PCP) prophylaxis, hepatitis B and C serology, the results of these tests (positive versus negative), use of ART (antiretroviral therapy), and care by a multidisciplinary team (annotation on the patient chart of having been seen by a professional other than physicians or the nursing staff).

In the years 1998 and 1999, the criteria for classifying AIDS cases were: CD4 T-cell count (less than $350 / \mathrm{mm}^{3}$ independently of symptoms); Rio de Janeiro/Caracas criterion, modified CDC criterion (Centers for Disease Control and Preven- tion), and death ${ }^{3}$. The latter was not considered in the current study, as mentioned previously.

Positive hepatitis B serology was defined as positive for least one of the two serological markers for this infection, except when only anti-Hbs was reactive, which was interpreted as a marker of vaccination.

The dependent variable, survival time, was calculated as date of diagnosis to date of death for patients that died, and date of diagnosis to date of the last visit to the health service for any reason for patients that survived, i.e., for those in whom there was no record of death. To update the information on patient follow-up or death, the database for this study was linked to the following national databanks: Mortality Information System (SIM), Information System on Laboratory Exams (SISCEL), and Logistics Control System for Medicines (SICLOM). The databank linkage used reclink, and the parameters for comparison were: patient's full name, date of birth, and patient's mother's full name, and the State of residence was not used in the blocking key. The study excluded patients for whom there was no record of having visited the service after diagnosis in either the patient charts or the above-mentioned databanks.

The study data were keyed into the database using Epi Info 6.04 (CDC, Atlanta, USA).

Patient proportions were estimated according to categories of the independent variables, and the differences between the two regions were evaluated with the chi-square test. Survival analysis used the Kaplan-Meier method, also used to calculate the percentages of survivors for different times since diagnosis. Comparison between the categories of study variables in relation to patient survival used Cox regression models. Significance for the statistical tests was set at 0.05.

Weights were introduced into the data analysis in order to compensate for different patient selection probabilities. The analyses used the Stata 10 statistical package (Stata Corp., College Station, USA) by means of the svy module, which allows incorporating aspects referring to the sample design (weighting, stratification, and cluster selection) in the estimates, except those referring to percentages of survivors for given times since diagnosis, estimated with the KaplanMeier method.

The study was approved by the Institutional Review Board of the Center for Referral and Training in STD/AIDS under the São Paulo State Health Department (Case no. 15/05 of June 20, 2005). It was also approved by research ethics committees at various university hospitals and some municipal health departments. 


\section{Findings}

This study considered 3,130 cases of AIDS patients, of which 1,150 from the South and 1,980 from the Southeast of Brazil. It was possible to find patient charts and obtain the essential data for completing the forms for 2,692 patients (996 from the South and 1,696 from the Southeast), corresponding respectively to $86.6 \%$ and $85.7 \%$ of the cases. Analysis of the data's consistency led to the exclusion of 601 questionnaires due to diagnostic dates other than 1998 or 1999; deaths less than 7 days after diagnosis; and cases that failed to meet any of the AIDS criteria. The final sample consisted of 2,091 cases, 782 from the South and 1,309 from the Southeast, representing, respectively, $68 \%$ and $66.1 \%$ of the initial sample.

The study population had the following characteristics: most were male (male-to-female ratio 1.85); $52.7 \%$ were diagnosed in 1998; and $54.4 \%$ had a maximum of complete primary schooling (Table 1). The socio-demographic profile differed in some aspects between the two regions. In the South, the patients were younger $34.1 \%$ were under 30 years of age), showed higher proportions of white race/skin color, were married or in common-law marriages, and showed more exposure from injecting drug use, $29.4 \%$ compared to $14.9 \%$ in the Southeast, although the latter showed a higher proportion of missing information for exposure category. Importantly, the sample did not include any AIDS cases due to vertical transmission. The amount of missing information was also high for some variables and was generally higher in the Southeast.

As for the diagnostic criterion, co-morbidities, and treatment: $50.9 \%$ were diagnosed based on CD4 T-cell count; $25.3 \%$ presented tuberculosis at the time of AIDS diagnosis or during evolution of the disease; $86 \%$ used ART; $54.2 \%$ were tested for hepatitis B, of which $31.7 \%$ tested positive, and $51.9 \%$ were tested for hepatitis $\mathrm{C}$, of which $26.7 \%$ were positive. In the set of patients, $16.4 \%$ had a diagnosis of hepatitis B $(19.3 \%$ in the Southeast and $11.4 \%$ in the South) and $14.1 \%$ had hepatitis C (12.8\% in the Southeast and $18.4 \%$ in the South); $42.6 \%$ had prophylaxis for Pneumocystis jirovecii pneumonia, and $41.4 \%$ were treated at a service with a multidisciplinary health team (Table 2). The only significant differences between the regions were: a higher rate of positive serology for hepatitis B in the Southeast and hepatitis C in the South.

Patients in the IDU exposure category showed the lowest survival probabilities in the two regions (Figure 1). The lowest percentages (below $50 \%$ ) of survivors 108 months after diagnosis were observed in the IDU exposure category in both regions and among black/brown patients in the Southeast and widowed individuals in the South. The greatest survival rates (proportions of survivors greater than $70 \%$ ) in both regions were in patients with more than primary schooling, and in the Southeast only, among individuals in the MSM (men who have sex with men) sexual exposure category (Table 3).

When observing the categories for the variables related to diagnosis, co-morbidities, and treatment, extremely low proportions of survivors (less than 15\%) were seen among patients not on ART (Table 4). At the other extreme, both regions showed survivor rates greater than $70 \%$ in patients with CD4 T-cell count as the diagnostic criterion and those not infected with hepatitis $\mathrm{C}$ virus. In the Southeast, higher survivor rates were also seen in patients tested for hepatitis B and C and those with negative hepatitis B serology.

Table 5 shows the univariate analysis, revealing the mortality risk in both regions was significantly higher in males, patients with less schooling, in the IDU or missing exposure categories, in patients diagnosed according to a criterion other than CD4 T-cell count, those not on ART, those not tested for hepatitis B or C, and those with positive hepatitis $C$ serology. In the South only, the risk of dying was also greater in patients 40 years or older and in single, separated, or widowed patients. In the Southeast only, risk of dying was greater in black or brown patients (hazard ratio - HR $=1.42$ ), those treated in health services without other professionals besides physicians and nurses, those with a diagnosis of tuberculosis $(\mathrm{HR}=1.75)$ sometime during their follow-up, those who did not receive Pneumocystis prophylaxis, and those who tested positive for hepatitis B.

Table 6 shows the variables that were maintained in the multiple regression model, as associated with mortality risk. The models for both regions maintained the following: gender, schooling, ART, and diagnostic criterion. The following were also kept in the model in the Southeast only: race/color, hepatitis B serology, tuberculosis, and having been seen by a multidisciplinary team. In the South, the age variable remained in the model.

\section{Discussion}

This study's main findings were the survival estimates and their determinants in the cohort of AIDS patients diagnosed in 1998-1999 in the South and Southeast regions of Brazil, after 8-10 years of follow-up. The study also showed an evident increase in the survival of these patients 
Socio-demographic and exposure characteristics of AIDS patients. South and Southeast regions of Brazil, 1998-1999 cohort.

\begin{tabular}{|c|c|c|c|c|c|c|c|}
\hline \multirow[t]{2}{*}{ Characteristic } & \multicolumn{2}{|c|}{ Southeast } & \multicolumn{2}{|c|}{ South } & \multicolumn{2}{|c|}{ Total } & \multirow{2}{*}{ p-value * } \\
\hline & $\mathrm{n}$ & $\%$ & $\mathrm{n}$ & $\%$ & $\mathrm{n}$ & $\%$ & \\
\hline Total & 1,309 & 62.6 & 782 & 37.4 & 2,091 & 100.0 & \\
\hline Gender & & & & & & & 0.723 \\
\hline Male & 853 & 65.2 & 504 & 64.5 & 1,357 & 65.0 & \\
\hline Female & 456 & 34.8 & 278 & 35.5 & 734 & 35.0 & \\
\hline Age (years) & & & & & & & 0.035 \\
\hline $13-29$ & 356 & 27.2 & 267 & 34.1 & 623 & 28.8 & \\
\hline $30-39$ & 563 & 43.0 & 315 & 40.3 & 878 & 42.4 & \\
\hline$\geq 40$ & 390 & 29.8 & 200 & 25.6 & 590 & 28.8 & \\
\hline Race/color & & & & & & & 0.001 \\
\hline White & 615 & 47.0 & 480 & 61.4 & 1,095 & 50.4 & \\
\hline Black & 86 & 6.6 & 71 & 9.1 & 157 & 7.2 & \\
\hline Brown & 212 & 16.2 & 50 & 6.4 & 262 & 13.9 & \\
\hline Other & 6 & 0.4 & 2 & 0.3 & 8 & 0.4 & \\
\hline Missing & 390 & 29.8 & 179 & 22.9 & 569 & 28.2 & \\
\hline Marital status & & & & & & & 0.007 \\
\hline Single & 519 & 39.7 & 258 & 33.0 & 777 & 38.1 & \\
\hline Married & 315 & 24.1 & 239 & 30.6 & 554 & 25.6 & \\
\hline Common law & 81 & 6.2 & 67 & 8.6 & 148 & 6.7 & \\
\hline Separated & 116 & 8.9 & 47 & 6.0 & 163 & 8.2 & \\
\hline Widowed & 67 & 5.1 & 28 & 3.6 & 95 & 4.8 & \\
\hline Information missing & 211 & 16.1 & 143 & 18.3 & 354 & 16.6 & \\
\hline Year of diagnosis & & & & & & & 0.641 \\
\hline 1998 & 686 & 52.4 & 419 & 53.6 & 1,105 & 52.7 & \\
\hline 1999 & 623 & 47.6 & 363 & 46.4 & 986 & 47.3 & \\
\hline Schooling & & & & & & & 0.844 \\
\hline$\leq$ Primary & 672 & 51.3 & 505 & 64.6 & 1,177 & 54.4 & \\
\hline Secondary/University & 309 & 23.6 & 225 & 28.8 & 534 & 24.8 & \\
\hline Missing & 328 & 25.1 & 52 & 6.7 & 380 & 20.7 & \\
\hline Exposure category & & & & & & & 0.001 \\
\hline Sexual & 878 & 67.1 & 518 & 66.3 & 1,396 & 66.9 & \\
\hline IDU & 195 & 14.9 & 230 & 29.4 & 425 & 18.3 & \\
\hline Blood, non-IDU & 6 & 0.5 & 1 & 0.1 & 7 & 0.4 & \\
\hline Missing & 230 & 17.6 & 33 & 4.2 & 263 & 14.4 & \\
\hline
\end{tabular}

IDU: injecting drug user.

* $\chi^{2}$ test performed without the "missing" category and corrected for sampling design.

when compared to previous studies performed with a similar design 12,13. Marins et al. 13 found a median survival of 58 months when analyzing a nationwide patient cohort, diagnosed in 1996, while in the current cohort it was not possible to calculate the median, since approximately $60 \%$ of the patients were alive at 108 months after diagnosis of the disease. Thus, survival had more than doubled in the two years separating one cohort from the other.
In the United States, according to a survival study on adults with AIDS diagnosed from 1996 to 2003 , more than $75 \%$ of the patients survived for at least 108 months 15, although the study identified significant variations in the percentages of survivors according to race/ethnicity and age bracket.

Cox multiple regression analysis pointed to different models for the Southeast and South regions of Brazil, but some variables proved 
Table 2

AIDS patients according to diagnosis, co-morbidity, and treatment. South and Southeast regions, 1998-1999 cohort.

\begin{tabular}{|c|c|c|c|c|c|c|c|}
\hline \multirow[t]{2}{*}{ Characteristic } & \multicolumn{2}{|c|}{ Southeast } & \multicolumn{2}{|c|}{ South } & \multicolumn{2}{|c|}{ Total } & \multirow[t]{2}{*}{ p-value * } \\
\hline & $\mathrm{n}$ & $\%$ & $\mathrm{n}$ & $\%$ & $\mathrm{n}$ & $\%$ & \\
\hline Total & 1,309 & 62.6 & 782 & 37.4 & 2,091 & 100.0 & \\
\hline Diagnostic criterion & & & & & & & 0.183 \\
\hline Modified CDC & 338 & 25.8 & 173 & 22.1 & 511 & 24.9 & \\
\hline Rio de Janeiro/Caracas & 263 & 20.1 & 217 & 27.7 & 480 & 21.9 & \\
\hline CD4 T-cell count & 671 & 51.3 & 388 & 49.6 & 1,059 & 50.9 & \\
\hline Missing & 37 & 2.8 & 4 & 0.5 & 41 & 2.3 & \\
\hline Tuberculosis & & & & & & & 0.206 \\
\hline Yes & 965 & 26.3 & 608 & 22.3 & 518 & 25.3 & \\
\hline No & 344 & 73.7 & 174 & 77.7 & 1,573 & 74.7 & \\
\hline ART & & & & & & & 0.526 \\
\hline Yes & 1,116 & 85.3 & 692 & 88.5 & 1,808 & 86.0 & \\
\hline No & 111 & 8.5 & 59 & 7.5 & 170 & 8.3 & \\
\hline Missing & 82 & 6.3 & 31 & 4.0 & 113 & 5.7 & \\
\hline HBV serology & & & & & & & 0.3614 \\
\hline Tested & 739 & 56.5 & 394 & 50.4 & 1,133 & 54.2 & \\
\hline Not tested/Not recorded & 570 & 43.5 & 388 & 49.6 & 958 & 45.0 & \\
\hline HBV test result & & & & & & & 0.0334 \\
\hline Positive & 253 & 34.2 & 89 & 22.6 & 342 & 31.7 & \\
\hline Negative & 486 & 65.8 & 305 & 77.4 & 791 & 68.3 & \\
\hline HCV serology & & & & & & & 0.8166 \\
\hline Tested & 689 & 52.6 & 397 & 50.8 & 1,086 & 51.9 & \\
\hline Not tested/Not recorded & 620 & 47.4 & 385 & 49.2 & 1,005 & 47.8 & \\
\hline $\mathrm{HCV}$ test result & & & & & & & 0.0097 \\
\hline Positive & 167 & 24.2 & 144 & 36.3 & 311 & 26.7 & \\
\hline Negative & 522 & 75.8 & 253 & 63.7 & 775 & 73.0 & \\
\hline PCP prophylaxis & & & & & & & 0.779 \\
\hline Reported & 552 & 42.2 & 345 & 44.1 & 897 & 42.6 & \\
\hline Not reported & 757 & 57.8 & 437 & 55.9 & 1.194 & 57.4 & \\
\hline Multidisciplinary team & & & & & & & 0.852 \\
\hline Yes & 537 & 41.0 & 333 & 42.6 & 870 & 41.4 & \\
\hline No & 772 & 59.0 & 449 & 57.4 & 1.221 & 58.6 & \\
\hline
\end{tabular}

* $\chi^{2}$ test performed without the "missing" category and corrected for sampling design.

ART: antiretroviral therapy; CDC: Centers for Disease Control and Prevention; HBV: hepatitis B virus; HCV: hepatitis C virus;

PCP: Pneumocystis pneumonia.

to be strong and consistent predictors in both regions: ART, diagnostic criterion, gender, and schooling. In the Southeast only, predictors of shorter survival included black/brown skin color as an indicator of lower socioeconomic status; co-morbidities like hepatitis B and history of tuberculosis; and a services organization variable, namely the presence of a multidisciplinary team. In the South, age remained in the final model.

Several of these predictors have also been identified by other authors in Brazil and elsewhere in the world 16,17,18,19,20.
The categories "use of ART" and "CD4 count as the diagnostic criterion" were consistently associated with longer survival in the South and Southeast, independently of gender and schooling. This indicates access to health services and antiretroviral therapy and early diagnosis. AIDS diagnosis according to CD4 T-cell count is more sensitive, captures patients earlier, and allows access to early preventive and therapeutic interventions. Late diagnosis of the disease has been identified as a predictor of mortality, even before the incorporation of the $\mathrm{CD} 4$ criterion by health services in Brazil 12. 


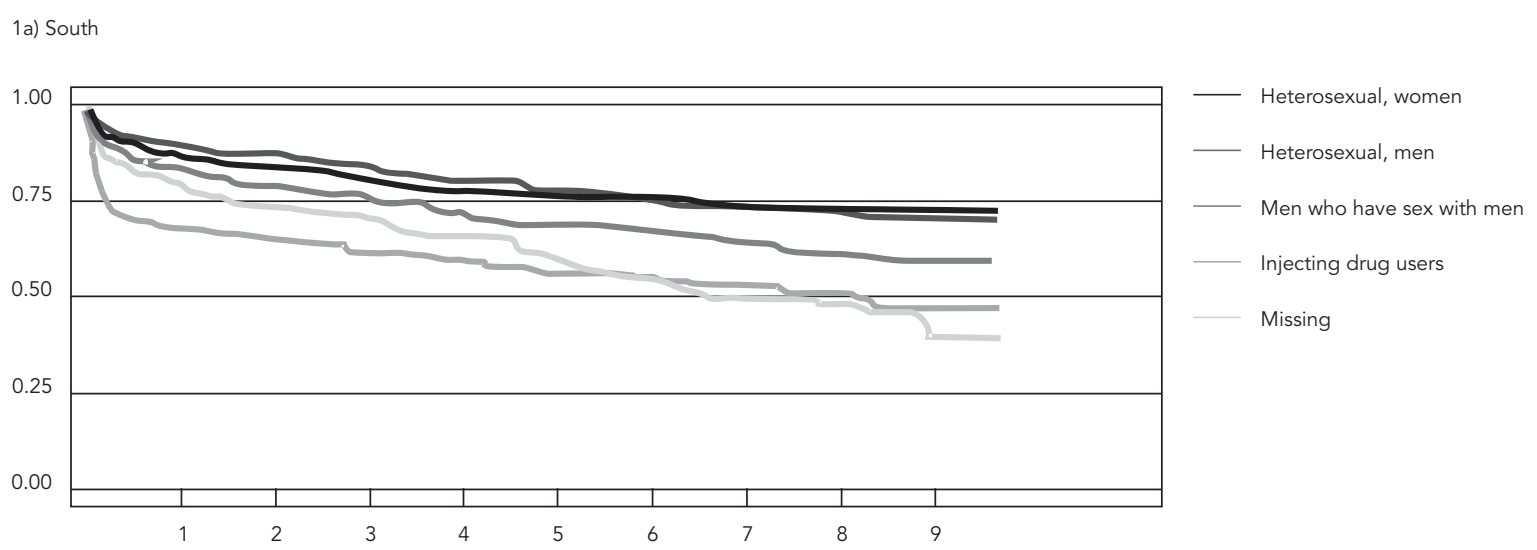

1b) Southeast
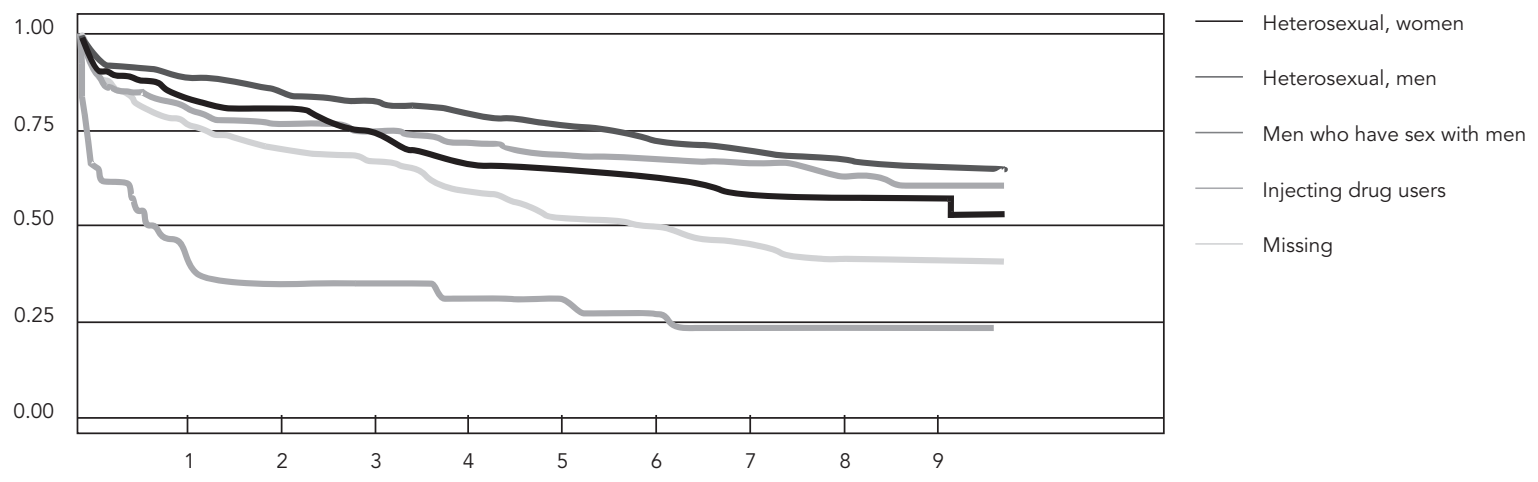

The availability of highly active antiretroviral therapy and adherence to the treatment regimen have been highlighted by various authors as essential for the effectiveness of individual treatment, besides decreasing the spread of viral resistance at the collective level. Meanwhile, the organization of health services and the comprehensive approach to patients can be decisive in improving clinical follow-up and improved treatment adherence, resulting longer survival $7,18,21,22$.

As for exposure category, survival was shorter among IDUs in both regions. Various authors have identified late diagnosis of the disease, difficulties in clinical follow-up, and lower treatment adherence as determinants of shorter survival in these patients 23,24 . There was a higher propor- tion of "missing" information on this variable in the Southeast when compared to the South, as observed in the National STD/AIDS Program 25, where the category "missing" accounts for $12 \%$ of the total for the country $(13.1 \%$ in the Southeast and $9 \%$ in the South).

According to the bivariate analysis, the findings in this 1998-1999 cohort point to higher mortality in males in both regions. Importantly, there was a major spread of the disease among IDU in the South, a group consisting mostly of young men. Longer survival in women could result from greater enrollment in (and use of) health services and prenatal care and childbirth (which increase the probability of performing diagnostic tests), and thus earlier diagnosis of HIV infection or AIDS. According to some stud- 
Percentage of AIDS patients with survival of at least 108 months and respective $95 \%$ confidence intervals $(95 \% \mathrm{Cl})$, according to geographic region and demographic and exposure characteristics. 1998-1999 cohort.

\begin{tabular}{|c|c|c|c|c|}
\hline \multirow[t]{2}{*}{ Characteristic } & \multicolumn{2}{|c|}{ Southeast } & \multicolumn{2}{|c|}{ South } \\
\hline & $\%$ & $95 \% \mathrm{Cl}$ & $\%$ & $95 \% \mathrm{Cl}$ \\
\hline Total & 59.5 & $56.3-62.5$ & 59.3 & $55.5-63.0$ \\
\hline \multicolumn{5}{|l|}{ Gender } \\
\hline Male & 56.4 & $52.4-60.2$ & 55.2 & $50.3-59.8$ \\
\hline Female & 65.2 & $59.9-70.0$ & 66.7 & $60.2-72.4$ \\
\hline \multicolumn{5}{|l|}{ Age (years) } \\
\hline $13-29$ & 61.3 & $55.2-66.7$ & 64.1 & $57.4-70.0$ \\
\hline $30-39$ & 59.9 & $54.8-64.6$ & 58.0 & $51.8-63.7$ \\
\hline$\geq 40$ & 57.3 & $51.5-62.6$ & 55.1 & $49.4-62.2$ \\
\hline \multicolumn{5}{|l|}{ Race/color } \\
\hline White & 61.2 & $56.6-65.4$ & 60.6 & $55.7-65.1$ \\
\hline Black/Brown & 46.6 & $39.5-53.4$ & 54.8 & $44.5-64.0$ \\
\hline \multicolumn{5}{|l|}{ Marital status } \\
\hline Single & 60.1 & $55.0-64.8$ & 50.1 & $43.2-56.5$ \\
\hline Married & 63.6 & $56.9-69.5$ & 63.2 & $56.4-69.2$ \\
\hline Common law & 60.8 & $48.1-71.3$ & 68.0 & $55.2-77.8$ \\
\hline Separated & 63.6 & $53.2-72.3$ & 61.0 & $44.8-73.7$ \\
\hline Widowed & 58.3 & $45.0-69.5$ & 49.9 & 18.075 .4 \\
\hline \multicolumn{5}{|l|}{ Year of diagnosis } \\
\hline 1998 & 57.3 & $53.0-61.3$ & 55.8 & $50.7-60.7$ \\
\hline 1999 & 63.8 & $59.6-67.7$ & 64.4 & $58.8-69.4$ \\
\hline \multicolumn{5}{|l|}{ Schooling } \\
\hline$\leq$ Complete primary & 55.3 & $50.7-59.6$ & 54.7 & $49.9-59.3$ \\
\hline Complete secondary/University & 70.2 & $64.0-75.6$ & 73.3 & $65.9-79.3$ \\
\hline \multicolumn{5}{|l|}{ Exposure category } \\
\hline Heterosexual, men & 58.8 & $51.9-64.9$ & 64.7 & $55.6-72.4$ \\
\hline Sexual, MSM & 72.0 & $65.3-77.7$ & 61.0 & $51.0-69.6$ \\
\hline Heterosexual, women & 69.8 & $63.9-74.9$ & 68.9 & $61.8-74.9$ \\
\hline IDU & 42.2 & $33.6-50.5$ & 48.6 & $41.6-55.2$ \\
\hline
\end{tabular}

IDU: injecting drug users; MSM: men who have sex with men.

ies, the association between gender and risk of dying is not maintained after controlling for socioeconomic variables and access to health services $1,13,17$.

Schooling was analyzed as a marker of the population's socioeconomic conditions, and was the only such information available on the patient chart disease notification forms. Individuals with complete secondary or university education showed lower risk of dying, compared to those with less schooling or with this information missing (the statistical significance remained in the final model in both regions). Higher AIDS mortality has been recorded in poor populations and countries, even with access to HAART. Factors possibly related to this excess risk include later diagnosis, higher prevalence of co-morbidities due to chronic invasive infections like tuberculosis, mycoses, and others, and more limited understanding and conditions to adhere to prolonged treatment, compared to population segments with higher schooling 7,19.

In the Southeast, even after adjusting for schooling, longer survival was shown in white individuals as compared toblackorbrown. Therace/ color variable (self-reported) was only incorporated into the AIDS investigation form in 200126. It is thus difficult to analyze trends, although recent years have seen a clear improvement in completion of the data: in 2000, $96 \%$ of reported AIDS cases lacked this information, whereas this proportion of missing information on race/color 
Percentage of AIDS patients with survival of at least 108 months according to diagnosis, co-morbidities, and treatment, and respective $95 \%$ confidence intervals $(95 \% \mathrm{Cl})$. 1998-1999 cohort.

\begin{tabular}{|c|c|c|c|c|}
\hline \multirow[t]{2}{*}{ Characteristic } & \multicolumn{2}{|c|}{ Southeast } & \multicolumn{2}{|c|}{ South } \\
\hline & $\%$ & $95 \% \mathrm{Cl}$ & $\%$ & $95 \% \mathrm{Cl}$ \\
\hline \multicolumn{5}{|l|}{ Diagnostic criterion } \\
\hline Modified CDC & 52.1 & $46.0-57.8$ & 45.6 & $37.8-53.1$ \\
\hline Rio de Janeiro/Caracas & 38.5 & $31.1-45.9$ & 48.7 & $41.4-55.5$ \\
\hline CD4 T-cell count & 71.2 & $66.9-75.1$ & 71.4 & $65.9-76.2$ \\
\hline \multicolumn{5}{|l|}{ Tuberculosis } \\
\hline Yes & 45.7 & $39.4-51.8$ & 49.7 & $41.7-57.1$ \\
\hline No & 64.2 & $60.6-67.6$ & 62.1 & $57.7-66.2$ \\
\hline \multicolumn{5}{|l|}{ ART } \\
\hline Yes & 67.2 & $63.9-70.3$ & 63.5 & $59.4-67.3$ \\
\hline No & 14.4 & $7.8-23.0$ & 10.5 & $3.8-21.1$ \\
\hline \multicolumn{5}{|l|}{ HBV serology } \\
\hline Tested & 73.7 & $69.8-77.2$ & 67.9 & $62.6-72.6$ \\
\hline Not tested/Not recorded & 39.7 & $34.8-44.6$ & 50.3 & 44.7-55.7 \\
\hline \multicolumn{5}{|l|}{ HBV test result } \\
\hline Positive & 69.7 & $62.6-75.8$ & 63.5 & $52.2-72.8$ \\
\hline Negative & 75.8 & $71.0-80.0$ & 69.2 & $63.2-74.5$ \\
\hline \multicolumn{5}{|l|}{ HCV serology } \\
\hline Tested & 75.1 & 71.1-78.7 & 67.4 & 62.1-72.1 \\
\hline Not tested/Not recorded & 41.0 & $36.2-45.6$ & 50.7 & $45.1-56.1$ \\
\hline \multicolumn{5}{|l|}{$\mathrm{HCV}$ test result } \\
\hline Positive & 65.4 & $55.4-73.6$ & 60.9 & $52.0-68.6$ \\
\hline Negative & 78.2 & 73.8-81.9 & 71.1 & $64.5-76.8$ \\
\hline \multicolumn{5}{|l|}{ PCP prophylaxis } \\
\hline No/not recorded & 53.9 & 49.7-57.9 & 62.5 & $57.5-67.2$ \\
\hline Yes & 67.1 & $62.2-71.5$ & 55.5 & 49.6-61.1 \\
\hline \multicolumn{5}{|l|}{ Multidisciplinary team } \\
\hline No & 52.6 & $48.4-56.6$ & 57.7 & $55.7-67.3$ \\
\hline Yes & 69.1 & $64.2-73.5$ & 61.8 & $52.7-62.3$ \\
\hline
\end{tabular}

ART: antiretroviral therapy; CDC: Centers for Disease Control and Prevention; HBV: hepatitis B virus; HCV: hepatitis C virus; PCP: Pneumocystis pneumonia.

dropped to only $15 \%$ by 200526,27 . In the South, even in the bivariate analysis, the race/color variable was not associated with survival.

Various authors have called attention to the difference in the risk of dying from AIDS according to race/skin color and ethnicity, attributing these differences to inequalities in access to health services and antiretroviral therapy, exposure to other diseases, and differences in living conditions. In Brazil, few studies have investigated this issue in depth $16,27,28,29$.

Fifty-two percent of patients in the sample had tested for hepatitis C, among whom $14 \%$ were seropositive, with no differences between the regions. This proportion of individuals tested for HCV was higher than observed in the study by Marins 30 (29,5\%), a difference that may result from the increase in survival, allowing more opportunities for performing HCV serology, besides indicating improved care. Prevalence of co-infection in that cohort (1995-1996) was $33.4 \%$, while in the current study (1998-1999 cohort) it was $26.7 \%$. The decrease in the proportion of AIDS cases among drug users in the last decade may have influenced this trend.

In relation to hepatitis $\mathrm{B}, 54 \%$ of the patients had done serological tests, of which $31.7 \%$ tested positive. In both regions, increased survival was related to fact that patients had been tested for hepatitis B and C. Early serological testing may 
Table 5

Hazard ratio (HR) estimates according to AIDS patients' characteristics. South and Southeast regions, 1998-1999 cohort.

\begin{tabular}{|c|c|c|c|c|}
\hline \multirow[t]{2}{*}{ Characteristic } & \multicolumn{2}{|c|}{ Southeast } & \multicolumn{2}{|c|}{ South } \\
\hline & $\mathrm{HR}$ & $\mathrm{p}$-value & HR & $\mathrm{p}$-value \\
\hline \multicolumn{5}{|l|}{ Gender } \\
\hline Male & 1 & & 1 & \\
\hline Female & 0.745 & 0.002 & 0.652 & 0.016 \\
\hline \multicolumn{5}{|l|}{ Age (years) } \\
\hline $13-29$ & 1 & & 1 & \\
\hline $30-39$ & 0.982 & 0.877 & 1.193 & 0.187 \\
\hline$\geq 40$ & 1.169 & 0.173 & 1.417 & 0.030 \\
\hline \multicolumn{5}{|l|}{ Schooling } \\
\hline$\leq$ Primary & 1 & & 1 & \\
\hline Secondary/University & 0.617 & 0.001 & 0.485 & 0.000 \\
\hline Missing & 1.024 & 0.889 & 1.667 & 0.099 \\
\hline \multicolumn{5}{|l|}{ Race/color } \\
\hline White & 1 & & 1 & \\
\hline Black/brown & 1.421 & 0.009 & 1.180 & 0.254 \\
\hline Missing & 0.844 & 0.178 & 1.153 & 0.562 \\
\hline \multicolumn{5}{|l|}{ Exposure category } \\
\hline Sexual & 1 & & 1 & \\
\hline IDU & 1.872 & 0.000 & 1.762 & 0.000 \\
\hline Blood (non IDU) + missing & 1.971 & 0.000 & 3.465 & 0.002 \\
\hline \multicolumn{5}{|l|}{ Diagnostic criterion } \\
\hline Modified CDC & 1 & & 1 & \\
\hline Rio de Janeiro/Caracas & 1.289 & 0.057 & 0.868 & 0.234 \\
\hline CD4 T-cell count & 0.417 & 0.000 & 0.344 & 0.000 \\
\hline Missing & 1.101 & 0.831 & 0.651 & 0.006 \\
\hline \multicolumn{5}{|l|}{ ART } \\
\hline Yes & 1 & & 1 & \\
\hline No & 10.209 & 0.000 & 8.328 & 0.000 \\
\hline Missing & 4.473 & 0.001 & 1.760 & 0.183 \\
\hline \multicolumn{5}{|l|}{ Multidisciplinary team } \\
\hline No & 1 & & 1 & \\
\hline Yes & 0.515 & 0.001 & 0.771 & 0.166 \\
\hline \multicolumn{5}{|l|}{ Year of diagnosis } \\
\hline 1998 & 1 & & 1 & \\
\hline 1999 & 0.910 & 0.356 & 0.769 & 0.205 \\
\hline \multicolumn{5}{|l|}{ Marital status } \\
\hline Single & 1 & & 1 & \\
\hline Married & 0.840 & 0.296 & 0.672 & 0.031 \\
\hline Common law & 0.942 & 0.695 & 0.602 & 0.024 \\
\hline Separated & 0.881 & 0.436 & 0.775 & 0.330 \\
\hline Widowed & 1.004 & 0.987 & 0.635 & 0.262 \\
\hline Information missing & 1.332 & 0.244 & 0.603 & 0.048 \\
\hline \multicolumn{5}{|l|}{ HBV serology } \\
\hline Not tested/Not recorded & 1 & & 1 & \\
\hline Tested & 0.297 & 0.000 & 0.525 & 0.003 \\
\hline
\end{tabular}

(continues) 
Table 5 (continued)

\begin{tabular}{|c|c|c|c|c|}
\hline \multirow[t]{2}{*}{ Characteristic } & \multicolumn{2}{|c|}{ Southeast } & \multicolumn{2}{|c|}{ South } \\
\hline & HR & $p$-value & HR & p-value \\
\hline \multicolumn{5}{|l|}{ HBV test result } \\
\hline Positive & 1 & & 1 & \\
\hline Negative & 0.732 & 0.045 & 0.795 & 0.183 \\
\hline Not tested/Not recorded & 2.768 & 0.000 & 1.601 & 0.000 \\
\hline \multicolumn{5}{|l|}{ HCV serology } \\
\hline Not tested/Not recorded & 1 & & 1 & \\
\hline Tested & 0.288 & 0.000 & 0.550 & 0.022 \\
\hline \multicolumn{5}{|l|}{$\mathrm{HCV}$ test result } \\
\hline Positive & 1 & & 1 & \\
\hline Negative & 0.671 & 0.008 & 0.671 & 0.032 \\
\hline Not tested/Not recorded & 2.602 & 0.000 & 1.428 & 0.132 \\
\hline \multicolumn{5}{|l|}{ Tuberculosis } \\
\hline No & 1 & & 1 & \\
\hline Yes & 1.756 & 0.000 & 1.449 & 0.073 \\
\hline \multicolumn{5}{|l|}{ PCP prophylaxis } \\
\hline No & 1 & & 1 & \\
\hline Yes & 0.572 & 0.005 & 1.119 & 0.585 \\
\hline
\end{tabular}

ART: antiretroviral therapy; CDC: Centers for Disease Control and Prevention; IDU: injecting drug user; HBV: hepatitis B virus; HCV: hepatitis C virus; PCP: Pneumocystis pneumonia.

\section{Table 6}

Results of Cox multiple regression analysis, indicating variables associated with survival of AIDS patients in the Southeast and South of Brazil, 1998-1999 cohort.

\begin{tabular}{|c|c|c|c|c|}
\hline \multirow[t]{2}{*}{ Variables } & \multicolumn{2}{|c|}{ Southeast } & \multicolumn{2}{|c|}{ South } \\
\hline & HR & p-value & HR & p-value \\
\hline \multicolumn{5}{|l|}{ Gender } \\
\hline Male & 1 & & 1 & \\
\hline Female & 0.78 & 0.042 & 0.61 & 0.002 \\
\hline \multicolumn{5}{|l|}{ Schooling } \\
\hline$\leq$ Primary & 1 & & 1 & \\
\hline Secondary/University & 0.61 & 0.004 & 0.53 & 0.001 \\
\hline Missing & 0.75 & 0.105 & 1.67 & 0.042 \\
\hline \multicolumn{5}{|l|}{ Age (years) } \\
\hline $13-29$ & & & 1 & \\
\hline $30-39$ & & & 1.05 & 0.721 \\
\hline$\geq 40$ & & & 1.43 & 0.007 \\
\hline \multicolumn{5}{|l|}{ Race/color } \\
\hline White & 1 & & & \\
\hline Black & 1.44 & 0.021 & & \\
\hline Brown & 1.33 & 0.034 & & \\
\hline Missing & 0.72 & 0.040 & & \\
\hline \multicolumn{5}{|l|}{ ART } \\
\hline Yes & 1 & & 1 & \\
\hline No & 6.42 & 0.000 & 6.77 & 0.000 \\
\hline Missing & 2.23 & 0.001 & 1.96 & 0.085 \\
\hline
\end{tabular}

(continues) 


\begin{tabular}{|c|c|c|c|c|}
\hline \multirow[t]{2}{*}{ Variables } & \multicolumn{2}{|c|}{ Southeast } & \multicolumn{2}{|c|}{ South } \\
\hline & HR & $\mathrm{p}$-value & HR & p-value \\
\hline \multicolumn{5}{|l|}{ Diagnostic criterion } \\
\hline Modified CDC & 1 & & 1 & \\
\hline Rio de Janeiro/Caracas & 1.13 & 0.470 & 0.84 & 0.096 \\
\hline CD4 T-cell count & 0.61 & 0.006 & 0.41 & 0.000 \\
\hline Missing & 0.81 & 0.527 & 0.62 & 0.002 \\
\hline \multicolumn{5}{|l|}{ HBV serology } \\
\hline Positive & 1 & & & \\
\hline Negative & 0.77 & 0.040 & & \\
\hline Not tested/Not recorded & 1.91 & 0.000 & & \\
\hline \multicolumn{5}{|l|}{ Multidisciplinary team } \\
\hline Yes & 1 & & & \\
\hline No & 1.44 & 0.001 & & \\
\hline \multicolumn{5}{|l|}{ Tuberculosis } \\
\hline No & 1 & & & \\
\hline Yes & 1.60 & 0.003 & & \\
\hline
\end{tabular}

ART: antiretroviral therapy; CDC: Centers for Disease Control and Prevention; HBV: hepatitis B virus; HR: hazard ratio.

be associated with increased survival, and recording serological results on the patient chart may reflect better quality of care. Importantly, there was an increased risk of mortality in patients co-infected with hepatitis B as compared to HBV-negative patients, even after adjusting for all the other variables included in the final model in the Southeast region. Various studies cited by Ferreira \& Borges 31 demonstrated greater risk of dying in patients with HIV/HBV co-infection, especially in those with low CD4 T-lymphocyte counts, as well as chronic alcoholics.

HIV/TB co-infection only contributed to reduction in survival in the Southeast. Other studies have reported worse AIDS prognosis in the presence of tuberculosis 11,30,32.

In the Southeast, AIDS mortality was lower in patients attending health services with a multidisciplinary team, i.e., with nutritionists, physical therapists, psychologists, and other professionals. The healthcare system in this region has a better infrastructure, with a consolidated system for distribution of medicines, as compared to other regions of Brazil. According to data from QUALIAIDS, in the South, $22.1 \%$ of services are classified as having better quality, while in the Southeast the proportion is $32 / .2 \% 33$. In an evaluation on quality of care for patients with HIV/
AIDS in seven Brazilian States, Melchior et al. 34 highlight the importance of having such professionals (in addition to physicians and nurses) in the health teams, even though these services are accessed mainly through referral by the attending physician.

One of the current study's limitations is that it analyzed secondary data, obtained from patient charts, implying a variation in quality, loss of data, and lack of data completeness. However, the calculated sample considered the possibility of losses, and the number of completed questionnaires allowed estimates with an adequate degree of precision that can be compared to previous studies, and to evaluate the increase in survival over time.

Despite major social disparities between Brazil's geographic regions and different AIDS transmission dynamics, this study points to an important gain in survival in patients with AIDS diagnosis in the two regions studied here: approximately $60 \%$ of the AIDS patients survived for at least 108 months. The findings also show persistent major challenges common to both the South and Southeast, including expansion of access to therapy and upgrading of healthcare services. 


\section{Resumo}

O estudo objetivou avaliar o tempo de sobrevida de pacientes de AIDS, com 13 anos ou mais de idade, das regiões Sul e Sudeste do país, segundo características sóciodemográficas e clínico-epidemiológicas. A amostra foi sorteada a partir da totalidade dos casos notificados no Sistema de Vigilância Epidemiológica do Programa Nacional de DST/AIDS, diagnosticados em 1998 e 1999. Utilizando-se questionário foi possível analisar 2.091 prontuários médicos. Pelo método Kaplan-Meier, foi estimada sobrevivência de pelo menos 108 meses após o diagnóstico em 59,5\% dos pacientes no Sudeste e 59,3\% no Sul. Por meio de modelos de regressão de Cox, foi verificado, nas duas regiões, aumento da sobrevivência nos pacientes que usaram antirretrovirais, que foram classificados como caso de AIDS pelo critério $C D 4$, que eram do sexo feminino e com maior escolaridade. Os fatores associados a tempos maiores de sobrevida no Sudeste foram ainda: possuir cor da pele branca, não ter tido tuberculose após seu diagnóstico de AIDS, não ser reagente à hepatite B e ter tido acesso à equipe multidisciplinar. No Sul, ter idade abaixo de 40 anos possibilitou maior sobrevida.

Síndrome de Imunodeficiência Adquirida; Sobrevida; Anti-Retrovirais; Mortalidade

\section{Contributors}

I. A. Guibu contributed to the study conception and design, data analysis and interpretation, drafting of the article, and revision and approval of the final version. M. B. A. Barros, M. C. G. P. Alves, and A. Tayra collaborated in the study conception and design, data analysis and interpretation, drafting of the article, and revision and approval of the final version. M. R. Donalísio collaborated in the data analysis and interpretation, drafting of the article, and approval of the final version.

\section{Acknowledgements}

The research was funded by the Brazilian National STD/ AIDS Program of the Ministry of Health, through an agreement with the Augusto Leopoldo Ayrosa Galvão Research Center, affiliated with the Faculdade de Ciências Médicas da Santa Casa de São Paulo. M. B. A. Barros received a productivity scholarship from the National Research Council (CNPq). Special acknowledgments to Gerson Fernando Pereira, José Ricardo Pio Marins, Artur Sousa, Magda Queiroz, Márcia Polon, Rejane Freissat, Lia Zangirolani, and Maria Aparecida Vedovato.

\section{References}

1. Fonseca MGP, Bastos FI. Twenty-five years of the AIDS epidemic in Brazil: principal epidemiological findings, 1980-2005. Cad Saúde Pública 2007; 23 Suppl 3:S333-44.

2. Ministério da Saúde. Boletim Epidemiológico AIDST 2008; Ano V, no. 1.

3. Ministério da Saúde. Critérios de definição de casos de AIDS em adultos e crianças. Brasília: Ministério da Saúde; 2004.

4. Dourado I, Veras MASM, Barreira D, Brito AM. Tendências da epidemia de AIDS no Brasil após a terapia antirretroviral. Rev Saúde Pública 2006; 40 Suppl:9-17.
5. Casseb J, Fonseca LA, Veiga AP, Almeida A, Bueno A, Ferez AC, et al. AIDS incidence and mortality in a hospital based cohort of HIV-1 seropositive patients receiving highly active antiretroviral therapy in São Paulo, Brazil. AIDS Patient Care STDS 2003; 17:447-52.

6. Crum NF, Riffemburg RH, Wegner S, Agan BK, Tasker SA, Spooner KM, et al. Comparison of causes of death and mortality rates among HIV infected persons: analysis of the pre, early, and late HAART (highly active antiretroviral therapy) eras. J Acquir Immune Defic Syndr 2006; 41:194-200. 
7. Santos NJS, Tayra A, Silva SR, Buchala CM, Laurenti R. A AIDS no estado de São Paulo: as mudanças no perfil da epidemia e perspectivas da vigilância epidemiológica. Rev Bras Epidemiol 2002; 5: 286-310.

8. Messeri P, Lee G, Abramson DM, Aidala A, Chiasson MA, Jessop DJ. Antiretroviral therapy and declining AIDS mortality in New York City. Med Care 2003; 41:512-21.

9. Vellozi C, Brooks JT, Bush TJ, Conley LJ, Henry K, Carperter CCJ, et al. The study to understand the natural history of HIV and AIDS in the era of effective therapy (SUN Study). Am J Epidemiol 2009; 169:642-52.

10. Quinn TC. HIV epidemiology and the effects of antiviral therapy on long term consequences. AIDS 2008; 22 Suppl 3:S7-S12.

11. Brazilian Ministry of Health. Targets and commitments made by the Member-States at the United Nation General Assembly Special Session on HIV/ AIDS. http//www.unaids.org/en/dataanalysis/m onitoringcountryprogress/2010progressreportss ubmittedbycountries/brazil_2010_country_progress_report_en.pdf (accessed on Jul/2010).

12. Chequer P, Hearst N, Hudes ES, Castilho E, Rutherford G, Loures L, et al. Determinants of survival in adult Brazilian AIDS patients, 1982-1989.The Brazilian State AIDS Program Co-ordinators. AIDS 1992; 6:483-7.

13. Marins JR, Jamal LE, Chen SY, Barros MB, Hudes ES, Barbosa AA, et al. Dramatic improvement in survival among adult Brazilian AIDS patients. AIDS 2003; 17:1675-82.

14. Collet D. Modeling survival data in medical research. 2nd Ed. Boca Raton: Chapman \& Hall; 2003.

15. Centers for Disease Control and Prevention. Epidemiology of HIV/AIDS, United States, 1981-2005. MMWR Morb Mortal Wkly Rep 2006; 55:589-92.

16. Wong KH, Chan KC, Lee SS. Delayed progression to death and to AIDS in a Hong Kong cohort of patients with advanced HIV type 1 disease during the era of highly active antiretroviral therapy. Clin Infect Dis 2004; 39:853-60.

17. Gadelha AJ, Accacio N, Costa RLB, Galhardo MC, Cotrim MR, Souza RV, et al. Morbidity and survival in advanced AIDS in Rio de Janeiro, Brazil. Rev Inst Med Trop São Paulo 2002; 44:179-86.

18. Hacker MA, Petersen ML, Enriquez M, Bastos FI. Highly active antiretroviral therapy in Brazil: the challenge of universal access in a context of social inequality. Rev Panam Salud Pública 2004; 16 : 78-83.

19. Krishnan S, Dunbar MS, Minnis AM, Medlin CA, Gerdts CE, Padian NS. Poverty, gender inequalities and women's risk of Human Immunodeficiency Virus/AIDS. Ann NY Acad Sci 2008; 1136:101-10.

20. Antunes JLF, Waldman EA, Borrel C. Is it possible to reduce AIDS death without reinforcing socioeconomic inequalities in health? Int J Epidemiol 2005; 34:586-92.
21. Castilho EA, Szwarcwald CL, Brito AM. Fatores associados à interrupção de tratamento anti-retroviral em adultos com AIDS, Rio Grande do Norte, Brasil, 1999-2002. Rev Assoc Med Bras (1992) 2006; 52:86-92.

22. Neme MIB, Carvalho HB, Souza MFM. ARV therapy adherence in Brazil. AIDS 2004; 18 Suppl 3:515-20.

23. Pérez-Hoyos S, Amo J, Muga R, Romero J, Olalla PG, Guerrero R, et al. Effectiveness of highly active antiretroviral therapy in Spanish cohorts of HIV seroconverters: differences by transmission category. AIDS 2003; 17:353-9.

24. Rapiti E, Porta D, Forastiere F, Fusco D, Perucci CA; Lazio AIDS Surveillance Collaborative Group. Socioeconomic status and survival of persons with AIDS before and after introduction of Highly Active Antiretroviral Therapy. Epidemiology 2000; 11:496-501.

25. Ministério da Saúde. Programa Nacional DST e AIDS. http://www.aids.gov.br/cgi/deftohtm.exe? tabnet/aids.def (accessed on 26/Aug/2009).

26. Giovanetti MC, Santos NJS, Westin CP, Darré D, Gianna MC. A implantação do quesito cor/raça nos serviços de DST/AIDS no Estado de São Paulo. Saúde Soc 2007; 16:163-70.

27. Fry PH, Monteiro S, Maio MC, Bastos FI, Santos RV. AIDS tem cor ou raça? Interpretação de dados e formulação de políticas de saúde no Brasil. Cad Saúde Pública 2007; 23:497-523.

28. Batista LE. Mulheres e homens negros: saúde, doença e morte [Doctoral Dissertation]. Araraquara: Fa-culdade de Ciências e Letras, Universidade Estadual Paulista; 2002.

29. Fonseca MGP, Lucena FFA, Souza A, Bastos FI. AIDS mortality, "race or color", and social inequality in a context of universal access to highly active antiretroviral therapy (HAART) in Brazil, 19992004. Cad Saúde Pública 2007; 23 Suppl 3:S445-55.

30. Marins JRP. Estudo de sobrevida dos pacientes de AIDS segundo escolaridade, co-infecção hepatite C e tuberculose. Coorte brasileira 1995-1996 [Doctoral Dissertation]. Campinas: Faculdade de Ciências Médicas, Universidade Estadual de Campinas; 2004.

31. Ferreira MS, Borges AS. Avanços no tratamento da hepatite pelo vírus B. Rev Soc Bras Med Trop 2007; 40:451-62.

32. Mussini C, Manzardo C, Johnson M, Monforte A, Uberti-Foppa C, Antinori A, et al. Patients presenting with AIDS in the HAART era: a collaborative cohort analysis. AIDS 2008; 22:2461-9.

33. Nemes MIB, Alencar TMD; Equipe Qualiaids. Avaliação da assistência ambulatorial aos adultos vivendo com HIV/AIDS. Qualiaids. Relatório 2007/2008. Brasília: Ministério da Saúde; 2008.

34. Melchior R, Nemes MIB, Basso CRB, Castanheira ERL, Alves MTSB, Buchalla CM, et al. Avaliação da estrutura organizacional assistência ambulatorial em HIV/AIDS no Brasil. Rev Saúde Pública 2006; 40:143-51.

Submitted on $21 / \operatorname{Jan} / 2010$

Final version resubmitted on 17/May/2010

Approved on 06/Jul/2010 